Gut, 1960, 1, 312.

\title{
ANEURYSM OF THE SPLENIC ARTERY
}

\author{
BY \\ P. D. BEDFORD and BRIAN LODGE
}

From the Cowley Road Hospital, Oxford

This paper records an incidence of $10.4 \%$ of aneurysm of the splenic artery in 250 consecutive routine post-mortem examinations. Medial degeneration seemed to be the commonest cause of such aneurysms and although a number were associated with other intraabdominal pathology, including portal hypertension, the association may be fortuitous and not causal.

Aneurysm of the splenic artery was first reported by Beaussier (1770). This and the second case reported by Parker (1844a and b) were for many years omitted from the literature and priority mistakenly given to Crisp (1847) by all subsequent authors, possibly because he himself had also erroneously credited Parker with the description of the first case.

The subject was last extensively reviewed by Owens and Coffey (1953) who found 198 cases described in the literature and added six more of their own. They mentioned an additional 12 cases, of which reports were too vague for them to include and a further 21 cases mentioned en passant in necropsy surveys, making a total altogether of 237 cases. A further 18 cases described since their review, together with seven cases of Turnbull (1915) which all previous surveys have curiously failed to include, brings the total in the world's literature to 262. The literature is largely made up of reports of a few cases derived incidentally from retrospective studies of large routine necropsy series and recorded often with little comment as rarities, or of clinical reports of either single cases or small groups of cases.

This communication seeks to establish that aneurysm of the splenic artery, far from being a rarity, is on the contrary a common condition. It sets out to explain how this fallacy has probably arisen; and to propose, in the light of the new evidence adduced, a revision of some widely held and generally accepted views and beliefs regarding the aetiology and treatment of the condition.

A comprehensive bibliography has been appended, including references to all previously recorded cases of aneurysm of the splenic artery.

\section{Source of DATA AND Method}

Following the chance discovery at necropsy of an unsuspected aneurysm of the splenic artery, a special study of the vessel was made in a consecutive series of 250 routine necropsies on patients dying at the Geriatric Unit, Cowley Road Hospital, Oxford.

The series comprises 108 males and 142 females, whose ages ranged respectively from 34 to 100 years (average 72) and 31 to 99 years (average 77). The distribution by age and sex is shown in Table I. All the patients were under the care of one of the authors; and assessment and morbid anatomical study of all 250 cases was conducted by both personally. The preponderance of females over males in the cases examined simply reflects the greater number of female admissions to this hospital and similar units throughout the country, which in turn reflects the progressively increasing proportion with age of elderly women in the general population in all quinquennia over 65 (cf. Registrar General's (1959) Statistical Review of England and Wales for 1957).

The method adopted at necropsy was to remove the spleen and pancreas en bloc and subsequently to make a complete dissection of the splenic artery. Where an aneurysm was disclosed, the preparation was fixed in $10 \%$ formol-saline. Injection of splenic arteries in no case brought to light an aneurysm not already revealed by dissection alone. The post-mortem examination included a careful study of the aorta and of the coronary and cerebral arteries.

\section{RESULTS}

Aneurysm of the splenic artery was found in 26 (eight men and 18 women) of the 250 routine consecutive necropsies, an incidence of $10.4 \%$ comprising $7 \cdot 4 \%$ of males (eight out of 108 ) and $12.9 \%$ of females (18 out of 142 ). All the aneurysms were symptomless and unsuspected and were all therefore quite incidental discoveries. The age of patients with aneurysm ranged from 50 to 80 years (average 71) in the males, and from 48 to 94 years (average 79) in the females (see Table I). Aneurysm of the splenic artery continues to be found at the rate of approximately 1 in 10 of all necropsies carried out in this hospital. 
TABLE I

AGE OF PATIENTS

\begin{tabular}{|c|c|c|c|c|c|c|c|c|c|}
\hline Age (years) & $30-39$ & $40-49$ & $50-59$ & $60-69$ & $70-79$ & $80-89$ & $90-99$ & 100 or over & Totals \\
\hline $\begin{array}{l}\text { Males } \\
\text { Aneurysms }\end{array}$ & $\begin{array}{l}1 \\
-\end{array}$ & $\begin{array}{l}1 \\
0 \\
-\end{array}$ & $\begin{array}{l}10 \\
1 \\
10 \%\end{array}$ & $\begin{array}{l}24 \\
2 \\
8 \cdot 3 \%\end{array}$ & $\begin{array}{l}41 \\
4 \\
9.8 \%\end{array}$ & $\begin{array}{l}26 \\
1 \\
4 \%\end{array}$ & $\begin{array}{r}4 \\
0 \\
-\end{array}$ & $\begin{array}{r}1 \\
0 \\
-\end{array}$ & $\begin{array}{c}108 \\
8 \\
7 \cdot 4 \%\end{array}$ \\
\hline $\begin{array}{l}\text { Females } \\
\text { Aneurysms }\end{array}$ & $\begin{array}{l}1 \\
0 \\
-\end{array}$ & $\begin{array}{c}3 \\
1 \\
33 \%\end{array}$ & $\begin{array}{r}13 \\
0 \\
-\end{array}$ & $\begin{array}{l}17 \\
21.7 \%\end{array}$ & $\begin{array}{l}42 \\
4 \\
9.5 \%\end{array}$ & $\begin{array}{l}48 \\
7 \\
14.6 \%\end{array}$ & $\begin{array}{l}18 \\
4 \\
22 \%\end{array}$ & $\begin{array}{r}\mathbf{0} \\
\mathbf{0} \\
-\end{array}$ & $\begin{array}{l}142 \\
18 \\
12.7 \%\end{array}$ \\
\hline $\begin{array}{l}\text { Total (M. and F.) } \\
\text { Aneurysms }\end{array}$ & $\begin{array}{r}2 \\
0 \\
-\end{array}$ & $\begin{array}{c}4 \\
1 \\
25 \%\end{array}$ & $\begin{array}{l}23 \\
1 \\
4 \cdot 3 \%\end{array}$ & $\begin{array}{l}41 \\
4 \\
9.8 \%\end{array}$ & $\begin{array}{l}83 \\
8 \\
9 \cdot 4 \%\end{array}$ & $\begin{array}{l}74 \\
8 \\
10.8 \%\end{array}$ & $\begin{array}{l}22 \\
4 \\
18 \%\end{array}$ & $\begin{array}{r}1 \\
0 \\
-\end{array}$ & $\begin{array}{l}250 \\
26 \\
10 \cdot 4 \%\end{array}$ \\
\hline
\end{tabular}

ANEURYSMS

\begin{tabular}{l|l}
\hline Overall average age $=76.4 \mathrm{yr}$. & $\begin{array}{l}\text { Male: average age } 70.9 \text { range } 50-80 \\
\text { Female: average age } 78.9 \text { range } 48-94\end{array}$ \\
\hline 250 necropsies overall average age $=74.9 \mathrm{yr}$. & $\begin{array}{l}\text { Male: average age } 72.2 \text { range } 34-100 \\
\text { Female: average age } 76.9 \text { range } 31-99\end{array}$ \\
\hline
\end{tabular}

Ratio of aneurysms male/female
Ratio of admissions male/female Ratio of admissions male/female
Ratio of all deaths male/female $=7 \cdot 4 \% / 12 \cdot 7 \%=1: 1 \cdot 7$.
$=2 / 3=1: 1 \cdot 5$. $=3 / 4=1: 1 \cdot 3$.

\section{Representative CaSe Reports}

CASE 1 (CRH No. 977).-A man of 50 had for two months complained of complete anorexia with nausea and epigastric pain some 20 minutes after meals. Examination revealed a fixed tender tumour in the epigastrium with multiple nodules in the liver. His blood pressure was $140 / 90 \mathrm{~mm} . \mathrm{Hg}$; the blood Wassermann and Kahn reactions were negative; a barium meal examination confirmed the clinical diagnosis of carcinoma of the stomach. He died 20 days after admission to hospital.

Necropsy confirmed the diagnosis made in life. The spleen weighed $150 \mathrm{~g}$. and measured $13 \mathrm{~cm} . \times 8 \mathrm{~cm} . \times$ $2 \mathrm{~cm}$; a splenunculus $3.5 \mathrm{~cm}$. in diameter was found near the lower pole of the spleen and a saccular aneurysm was present at the first bifurcation of the splenic artery where it gave off branches to the spleen and splenunculus

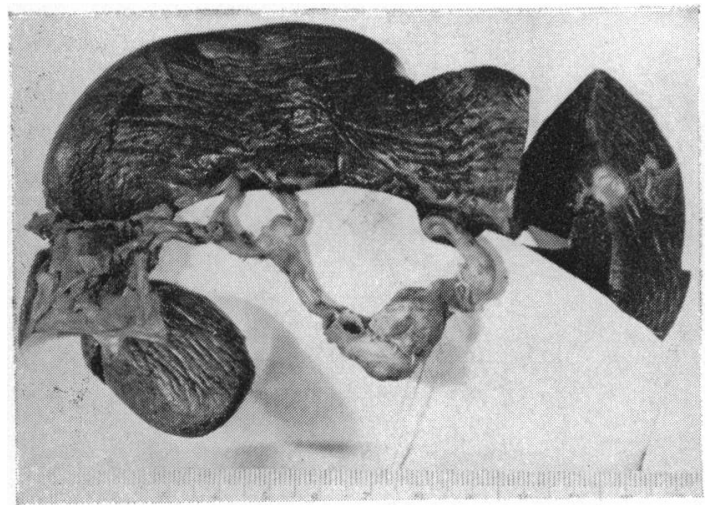

FIG. 1.-Spleen and splenunculus showing saccular aneurysm of the splenic artery (Case 1).
(Fig. 1). The aneurysm was $2.5 \mathrm{~cm}$. in diameter with a smooth surface and was not attached to neighbouring viscera; the splenic artery was $5 \mathrm{~mm}$. in diameter and relatively free from atheroma, but atheromatous plaques were present in the wall of the aneurysm. There was minimal atheroma only of the cerebral arteries and of the aorta. The heart and kidneys were normal. Histology of the aneurysm showed degeneration of the medial coat and the picture of true aneurysm (Turnbull, 1915) of the splenic artery with superadded atheroma (Fig. 2). (As this aneurysm is entirely representative of the findings in all the cases in the present series, further histological details and illustrations will not be given in the other case summaries cited here.)

CASE 3 (CRH No. 872).-A woman of 90 died of a posterior cardiac infarction 11 days after admission to hospital following a coronary thrombosis. Her blood

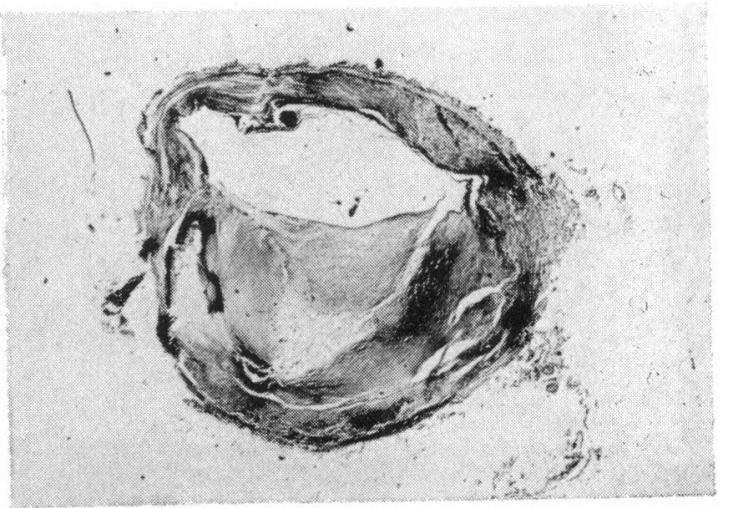

FIG. 2.-Histology of the aneurysm of the splenic artery in Fig. 1 showing medial degeneration with superadded atheroma. 


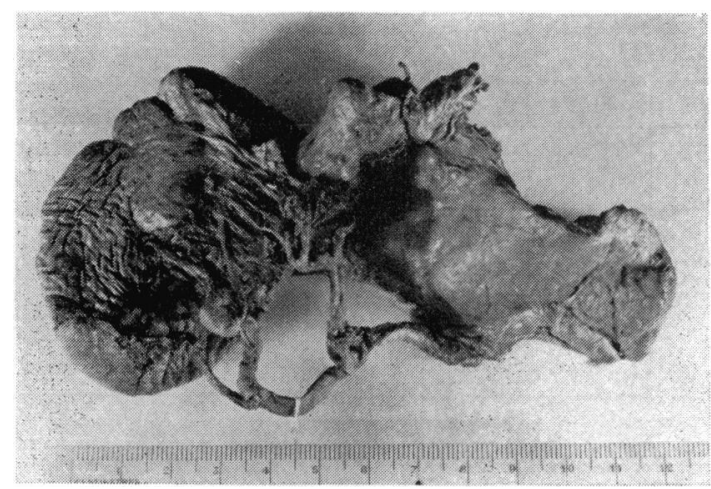

Fig. 3.-A saccular aneurysm at one of the branches of the splenic artery (Case 3).

pressure was $180 / 80 \mathrm{~mm}$. $\mathrm{Hg}$; the blood Wassermann and Kahn reactions were negative.

Necropsy confirmed the diagnosis of myocardial infarction of the posterior wall of the left ventricle, due to thrombosis of the right coronary artery. There was severe atheroma of the thoracic and abdominal aorta and of the cerebral arteries. An aneurysm of the abdominal aorta $2.5 \mathrm{~cm} \times 2.5 \mathrm{~cm}$. $\times 1 \mathrm{~cm}$. was found immediately distal to the coeliac axis on the left side of the aorta. The heart weighed $225 \mathrm{~g}$. and the spleen $120 \mathrm{~g}$. The spleen measured $7.7 \mathrm{~cm} . \times 5 \mathrm{~cm} . \times 2.5 \mathrm{~cm}$; there was no splenunculus; the splenic artery was tortuous and heavily atheromatous; an aneurysm $0.8 \mathrm{~cm}$. in diameter was present at the tertiary bifurcation of the vessel (Fig. 3).

CASE 8 (CRH No. 1137).-A man of 66, a known hypertensive for four years, had a first "stroke" six months before his admission to hospital with a second. He was found on examination to have the physical signs of a "supranuclear bulbar palsy". His blood pressure

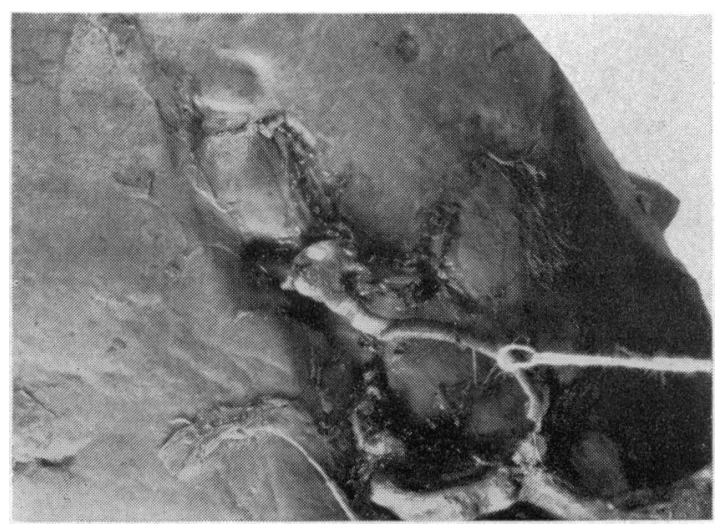

FIG. 4.-Aneurysm of one of the branches of the splenic artery (Case 8). was $250 / 140 \mathrm{~mm}$. $\mathrm{Hg}$; the ocular fundi showed Grade III hypertensive retinopathy; his urine on routine testing was normal; his blood urea was $30 \mathrm{mg}$. per $100 \mathrm{ml}$. and the blood Wassermann and Kahn reactions were negative. He died of bronchopneumonia five weeks later.

Necropsy showed bronchopneumonia of the lower lobes of both lungs. The heart weighed $550 \mathrm{~g}$., the left ventricle being grossly hypertrophied; the aorta and the coronary and cerebral arteries were heavily atheromatous. The unfixed brain on section showed multiple zones of old yellow softening scattered throughout both hemispheres and in the brain-stem. The kidneys were shrunken and scarred due to chronic pyelonephritis. The spleen weighed $180 \mathrm{~g}$. and measured $8 \mathrm{~cm} . \times 6 \mathrm{c.n} . \times$ $2.5 \mathrm{~cm}$.; there was no splenunculus; an aneurysm $3 \mathrm{~mm}$. in diameter was present at the bifurcation of the lowest (caudal) of the first three branches of the splenic artery (Fig. 4).

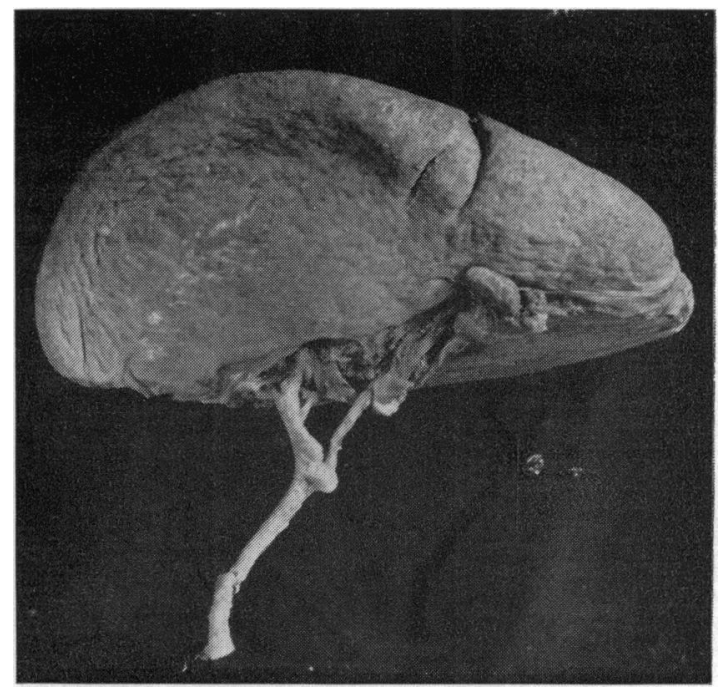

Fig. 5.-Aneurysm of one of the branches of the splenic artery (Case 13).

CASE 13. (CRH 986). - A woman of 82 was admitted to hospital with a two-year history of angina of effort. The heart was in sinus rhythm and was grossly enlarged: the blood pressure was $200 / 110 \mathrm{~mm}$. Hg: the electrocardiogram showed the pattern of a recent anterior myocardial infarction; the blood Wassermann and Kahn reactions were negative. She died in hospital following a second cardiac infarction six months later.

Necropsy confirmed the presence of an old anterior and a recent posterior cardiac infarction due to thrombosis of heavily atheromatous coronary arteries. The heart weighed $450 \mathrm{~g}$. There was gross generalized atherosclerosis of all arteries including the aorta, renal, coronary, cerebral, hepatic, and splenic. The spleen weighed $180 \mathrm{~g}$. and measured $10 \mathrm{~cm} . \times 5 \mathrm{~cm} . \times 3 \mathrm{~cm}$. 
TABLE II

CLINICAL DETAILS OF SERIES

\begin{tabular}{|c|c|c|c|c|c|c|c|c|c|c|}
\hline \multicolumn{2}{|c|}{ Case No. } & \multirow{2}{*}{$\begin{array}{c}\text { Age } \\
\text { (years) }\end{array}$} & \multirow{2}{*}{ Sex } & \multirow{2}{*}{$\begin{array}{l}\text { Blood } \\
\text { Pressure } \\
\text { (mm.Hg) }\end{array}$} & \multirow{2}{*}{ Principal Disease(s) } & \multirow{2}{*}{$\begin{array}{c}\text { Spleen } \\
\text { Weight } \\
\text { (g.) }\end{array}$} & \multirow{2}{*}{$\begin{array}{l}\text { Splenun- } \\
\text { culus }\end{array}$} & \multirow{2}{*}{$\begin{array}{l}\text { Congenital } \\
\text { Anomalies }\end{array}$} & \multirow{2}{*}{$\begin{array}{c}\text { Size of } \\
\text { Aneurysm } \\
\text { (cms.) }\end{array}$} & \multirow{2}{*}{ Situation } \\
\hline C.R.H. & Series & & & & & & & & & \\
\hline $\begin{array}{r}977 \\
1002 \\
872\end{array}$ & $\begin{array}{l}1 \\
2 \\
3\end{array}$ & $\begin{array}{l}50 \\
74 \\
90\end{array}$ & $\begin{array}{l}\mathbf{M} \\
\mathbf{M}\end{array}$ & $\begin{array}{l}140 / 90 \\
160 / 90 \\
180 / 80\end{array}$ & $\begin{array}{l}\text { Carcinoma of stomach } \\
\text { Tabes dorsalis } \\
\text { Carcinoma of stomach, }\end{array}$ & $\begin{array}{l}150 \\
180 \\
120\end{array}$ & $\frac{1}{二}$ & $\bar{z}$ & $\begin{array}{l}2.5 \\
1.0 \\
1.2\end{array}$ & $\begin{array}{l}\text { At main bifurcation } \\
\text { At second bifurcation } \\
\text { At third bifurcation }\end{array}$ \\
\hline $\begin{array}{r}859 \\
0 / 449\end{array}$ & $\begin{array}{l}4 \\
5\end{array}$ & $\begin{array}{l}64 \\
69\end{array}$ & $\underset{\mathbf{M}}{\mathbf{F}}$ & $\begin{array}{l}130 / 75 \\
170 / 70\end{array}$ & $\begin{array}{l}\text { myocardial infarction } \\
\text { Carcinoma of stomach } \\
\text { Serum positive "latent" } \\
\text { lues, carcinoma of pros- } \\
\text { tate, osteitis deformans, } \\
\text { myocardial infarction }\end{array}$ & $\begin{array}{l}140 \\
225\end{array}$ & 二 & 二 & $\begin{array}{l}0.8 \\
0.8\end{array}$ & $\begin{array}{l}\text { At main bifurcation } \\
\text { At main bifurcation }\end{array}$ \\
\hline 1034 & 6 & 80 & $\mathbf{F}$ & $150 / 80$ & $\begin{array}{l}\text { Myelofibrosis, carcinoma } \\
\text { of cervix }\end{array}$ & 600 & 1 & - & $\left\{\begin{array}{l}1.5 \\
0.5 \\
0.5\end{array}\right.$ & $\begin{array}{l}\text { At main bifurcation, on } \\
\text { trunk at second artery } \\
\text { on trunk at second } \\
\text { artery }\end{array}$ \\
\hline 1015 & 7 & 85 & $\mathbf{F}$ & $260 / 115$ & $\begin{array}{l}\text { Myxoedema, broncho- } \\
\text { pneumonia }\end{array}$ & 115 & - & $\begin{array}{l}\text { Polycystic kidneys } \\
\text { Aneurysm of Circle }\end{array}$ & 0.4 & On secondary trunk \\
\hline 1137 & 8 & 66 & $\mathbf{M}$ & $250 / 140$ & Essential hypertension, & 180 & - & or wims & $0 \cdot 3$ & At secondary bifurcation \\
\hline 883 & 9 & 77 & $\mathbf{M}$ & $120 / 70$ & $\begin{array}{l}\text { Bronchopeumonia, } \\
\text { bronchiectasis }\end{array}$ & 105 & - & - & 0.8 & At secondary bifurcation \\
\hline $0 / 190$ & 10 & 94 & $\mathbf{F}$ & $150 / 70$ & $\begin{array}{l}\text { Gangrene of leg due to } \\
\text { femoral artery throm- } \\
\text { bosis }\end{array}$ & 160 & - & $\begin{array}{l}\text { Cystic disease of pan- } \\
\text { creas, multiple re- } \\
\text { nal cysts + +ejunal } \\
\text { diverticula }\end{array}$ & 0.8 & On main trunk \\
\hline 1203 & 11 & 92 & $\mathbf{F}$ & $160 / 90$ & $\begin{array}{l}\text { Pulmonary embolism, } \\
\text { thyrotoxic heart failure } \\
\text { with atrial fibrillation }\end{array}$ & 210 & 1 & averncua & 0.7 & At secondary bifurcation \\
\hline 1049 & 12 & 77 & $\mathbf{F}$ & $270 / 140$ & $\begin{array}{l}\text { Essential hypertension, } \\
\text { gangrene of right leg due } \\
\text { to popliteal artery } \\
\text { thrombosis, multiple } \\
\text { cerebral thrombosis }\end{array}$ & 240 & - & $\begin{array}{l}\text { Osler's multiple here- } \\
\text { ditary } \\
\text { tasia }\end{array}$ & 1.5 & At secondary bifurcation \\
\hline $\begin{array}{r}986 \\
1550\end{array}$ & $\begin{array}{l}13 \\
14\end{array}$ & $\begin{array}{l}82 \\
80\end{array}$ & $\stackrel{\mathrm{F}}{\mathrm{M}}$ & $\begin{array}{l}200 / 110 \\
115 / 80\end{array}$ & $\begin{array}{l}\text { Myocardial infarction } \\
\text { Bronchopneumonia, chro- } \\
\text { nic pyelonephritis, be- } \\
\text { nign prostatic hyper- }\end{array}$ & $\begin{array}{l}180 \\
200\end{array}$ & 二 & 二 & $\begin{array}{l}0.4 \\
1.0\end{array}$ & $\begin{array}{l}\text { At secondary bifurcation } \\
\text { At main bifurcation }\end{array}$ \\
\hline 1339 & 15 & 48 & $\mathbf{F}$ & $140 / 70$ & $\begin{array}{l}\text { Tuberculous broncho- } \\
\text { pneumonia miliary }\end{array}$ & 400 & - & - & $1 \cdot 2$ & At secondary bifurcation \\
\hline 2138 & 16 & 92 & $\mathbf{F}$ & $200 / 100$ & $\begin{array}{l}\text { Bronchopneumonia, essen- } \\
\text { tial hypertension, cere- } \\
\text { bral thrombosis, cardiac } \\
\text { infarction }\end{array}$ & 140 & - & - & 0.5 & On trunk of main vessel \\
\hline 3414 & 17 & 74 & $\mathbf{F}$ & $130 / 60$ & $\begin{array}{l}\text { Diabetes mellitus, gan- } \\
\text { grene right leg, broncho- } \\
\text { pneumonia }\end{array}$ & 120 & - & - & 0.08 & At secondary bifurcation \\
\hline 3431 & 18 & 74 & $\mathbf{M}$ & $240 / 120$ & $\begin{array}{l}\text { Chronic pyelonephritis } \\
\text { with hypertension, car- } \\
\text { diac infarction, cerebral } \\
\text { thrombosis, broncho- } \\
\text { pneumonia }\end{array}$ & 180 & - & - & $1 \cdot 2$ & At secondary bifurcation \\
\hline 2858 & 19 & 78 & $\mathbf{F}$ & $140 / 80$ & $\begin{array}{l}\text { Diffuse lupus erythema- } \\
\text { tosus, carcinoma of } \\
\text { breast, pulmonary embo- } \\
\text { lism }\end{array}$ & 130 & - & - & $2 \cdot 0$ & At main bifurcation \\
\hline 162 & 20 & 60 & $\mathbf{F}$ & $180 / 110$ & $\begin{array}{l}\text { Rheumatoid arthritis, } \\
\text { acute-on-chronic pyelo- } \\
\text { nephritis with hyper- } \\
\text { tension and uraemia }\end{array}$ & 160 & $(2.5 \mathrm{cms})$. & - & 1.4 & At first bifurcation \\
\hline $0 / 453$ & 21 & 86 & $\mathbf{F}$ & $240 / 110$ & $\begin{array}{l}\text { Carcinoma of breast, } \\
\text { acute-on-chronic pyelo- } \\
\text { nephritis with hyper- } \\
\text { tension, bronchopneu- } \\
\text { monia }\end{array}$ & 140 & - & - & 0.6 & At secondary bifurcation \\
\hline 1785 & 22 & 86 & $\mathbf{F}$ & $140 / 85$ & $\begin{array}{l}\text { Carcinoma of urinary } \\
\text { bladder, massive pul- } \\
\text { monary embolism, cere- } \\
\text { bral thrombosis' }\end{array}$ & 120 & - & - & $\begin{array}{l}0.5 \\
0.7 \\
1.2\end{array}$ & $\begin{array}{l}\text { On main trunk at first } \\
\text { bifurcation } \\
\text { At second bifurcation }\end{array}$ \\
\hline 2789 & 23 & 80 & $\mathbf{F}$ & $230 / 120$ & $\begin{array}{l}\text { Essential } \\
\text { cerebral hertension, } \\
\text { thrombosis, } \\
\text { bronchopneumonia }\end{array}$ & 150 & - & - & 0.5 & On trunk of main vessel \\
\hline 3526 & 24 & 72 & $\mathbf{F}$ & $180 / 100$ & $\begin{array}{l}\text { Cerebral trombosis, dia- } \\
\text { betes mellitus, broncho- } \\
\text { pneumounia }\end{array}$ & 120 & - & - & 1.0 & At first bifurcation \\
\hline 69 & 25 & 77 & $\mathbf{M}$ & $210 / 110$ & $\begin{array}{l}\text { Osteitis deformans, essen- } \\
\text { tial hypertension, cere- } \\
\text { bral thrombosis, bron- } \\
\text { choneumonia }\end{array}$ & 160 & - & - & 0.5 & At first bifurcation \\
\hline 3541 & 26 & 81 & $\mathbf{F}$ & $130 / 75$ & $\begin{array}{l}\text { chopneumonia thrombosis, } \\
\text { chronic gastric ulcer }\end{array}$ & 120 & - & - & 0.4 & At secondary bifurcation \\
\hline
\end{tabular}


A thin-walled aneurysm $4 \mathrm{~mm}$. in diameter was present immediately proximal to the bifurcation of one of the primary branches of the splenic artery: no splenunculus was present (Fig. 5).

Data of the 26 cases are summarized in Table II. One case only (No. 15) was associated with septicaemia; none of the aneurysms was mycotic; only two cases (Nos. 5 and 2) gave a history or showed evidence of syphilitic infection but in neither did the aneurysm microscopically show evidence of a luetic aetiology; two cases (Nos. 6 and 15) were associated with significant enlargement of the spleen but neither had portal hypertension; four cases (Nos. 1, 6, 11, and 20) had splenunculi; and three cases (Nos. 7, 10, and 12) had congenital abnormalities of other systems. All the aneurysms were saccular and "true" as defined by Turnbull (1915), i.e., "dilatations of the artery bounded by one or more of the coats of the artery".

\section{INCIDENCE}

Textbooks have until recently made little or no reference to aneurysm of the splenic artery. The recent increase in the number of cases reported in the literature, and the surgical treatment recommended have, however, called attention to its existence; so that although Illingworth and Dick (1956) do not mention it at all, Muir (1958) does make scant reference to it as "an occasional finding". The condition is referred to, albeit very briefly, by both Holland and Bourne (1959) and by Rob and Smith (1956) in their textbooks of gynaecology and surgery respectively.

The combined post-mortem series of Emmerich (1888), Bosdorff (1889), Schrotter (1898), Müller (1902), Garland (1921), Ophüls (1926), Guy (1939), Sperling (1940), and Seids and Hauser (1941) totals 38 cases of aneurysm of the splenic artery out of 100,241 necropsies, an incidence of $0.03 \%$, ranging from $0.01 \%$ to $0.23 \%$ (Table III).

The present finding of aneurysm of the splenic artery in $10.4 \%$ of a consecutive series of routine necropsies may be thought to be due to a particular hospital selection or bias, for example in age group; but out of 825 necropsies performed by one of us in a precisely similar series in the same hospital before this series of specially studied cases, aneurysm of the splenic artery was recorded only twice. It is highly probable therefore that the difference between these figures for the incidence of aneurysm of the splenic artery depends entirely upon the care exercised in looking for it. As only two cases of aneurysm of the splenic artery were recorded among 825 necropsies, whereas 26 were found out of the next 250 when this feature was specifically looked for, and as both these series of necropsies were com-
TABLE III

INCIDENCE OF ANEURYSM OF THE SPLENIC ARTERY IN NECROPSY SURVEYS

\begin{tabular}{l|l|r|r}
\hline \multicolumn{1}{c|}{ Author } & Place & $\begin{array}{c}\text { Total } \\
\text { Ne- } \\
\text { cropsies }\end{array}$ & $\begin{array}{c}\text { No. of } \\
\text { Splenic } \\
\text { Artery } \\
\text { Aneurysms }\end{array}$ \\
\hline Emmerich (1888) & Munich & 8,669 & $1(0 \cdot 01 \%)$ \\
Bosdorff (1889) & Kiel & 3,108 & $7(0 \cdot 23 \%)$ \\
Von Schrotter (1898) & Vienna & 19,300 & $4(0 \cdot 02 \%)$ \\
Müller (1902) & Jena & 10,360 & $9(0 \cdot 087 \%)$ \\
Garland (1921) & Boston & 4,100 & $3(0 \cdot 073 \%)$ \\
Ophüls (1926) & Stanford & 3,000 & $1(0 \cdot 03 \%)$ \\
Guy (1939) & Chicago & 5,000 & $2(0 \cdot 04 \%)$ \\
Sperling (1940) & Minneapolis & 33,810 & $7(0 \cdot 02 \%)$ \\
Seids and Hauser (1941) & Cleveland & 12,894 & $4(0.03 \%)$ \\
\hline & Total & 100,241 & $38(0.03 \%)$ \\
\hline Springorum (1933) & - & 50 & $4(8 \%)$ \\
Ferrari (1938) & - & 143 & $14(9 \cdot 8 \%)$ \\
Bedford and Lodge (1960) & - & 250 & $26(10 \cdot 4 \%)$ \\
\hline
\end{tabular}

parable in respect of age, sex, and diseases, the latter incidence must certainly be construed as true and the former false. The common practice of examining the organs after their removal from the body either by the pathologist or the post-mortem attendant strongly militates against the discovery of aneurysm of the splenic artery, and especially if they are not large or unusually conspicuous.

As previous reports have been of isolated cases or have been concerned with large unselected series of necropsy records it may reasonably be inferred that the previously estimated incidence is erroneous and that the apparent rarity of aneurysm of the splenic artery is spurious. The true incidence of aneurysm of the splenic artery-and certainly in old people dying in hospital-is $10.4 \%$. Russell (personal communication) agrees that the condition is much more common than appears to be generally believed.

The series of necropsies reported by Springorum (1933) and Ferrari (1938), which have been given little or no attention in previous reviews, support the considerably higher incidence found by us. Springorum (1933) found four cases of aneurysm in 50 consecutive necropsies, and Ferrari (1938) found 14 out of 143 , an incidence of $8 \%$ and $9.8 \%$ respectively.

An unknown but probably considerable number of aneurysms of the splenic artery found incidentally at necropsy have undoubtedly not been recorded in the literature. Further evidence in support of the commonness of the condition is afforded by the many radiologists who have seen a number of aneurysms in practice (c.f. Fig. 6) although no large radiological series has as yet been published. The inference is inescapable that had these cases been recorded in the literature, the reported incidence of the condition would be more in keeping with that found in the present series. 


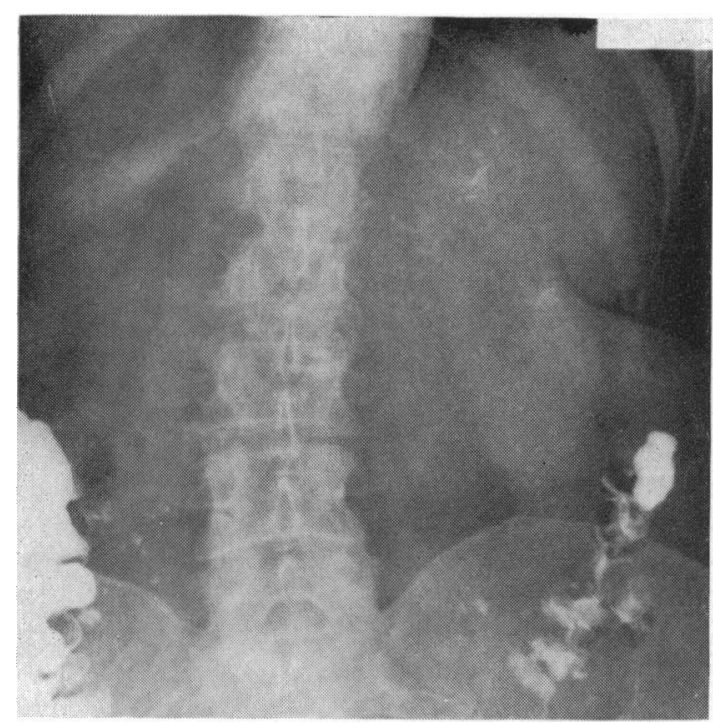

Fig. 6.-Multiple calcified aneurysms of the splenic artery shown incidentally by radiography.

\section{SEX INCIDENCE}

The crude sex ratio of males to females in the cases discussed by Owens and Coffey (1953) was $1: 2$ (63 males to 127 females) and by Sherlock and Learmonth (1942) $1: 1.78$ (42 males to 75 females). In the present series the crude ratio of males to females was $8: 18$, and the corrected sex ratio for numbers admitted is $7.4 \%$ to $12.7 \%$ or $1: 1.7$ of males to female.

Although these previous series and our own are not strictly comparable in that the former cases were not derived from a consecutive series, and a corrected sex incidence ratio is therefore not available, the figures are surprisingly similar.

The incidence of the condition is undoubtedly higher in females than in males and this is not to be explained by the greater number of female admissions to hospital nor by the greater number of females coming to post-mortem examination (see Table I). Sherlock and Learmonth (1942) state that “. . . splenic aneurysm sometimes declares itself during pregnancy and this may partly account for the larger number of females . ..."

We are unable to explain the greater incidence of this condition in females than in males but any immediate effect of pregnancy is certainly not applicable in our series.

This incidence is particularly interesting as aneurysms at all other common sites are undoubtedly more frequent in males.

\section{Age InCIDENCE}

The average age where this was known of the
113 cases discussed by Sherlock and Learmonth (1942) was 48 years, the youngest being 14 and the oldest 84 years. The average age in the series reviewed by Owens and Coffey (1953) was exactly the same, their series including 58 women of childbearing years and 31 who were pregnant. In the present series the average age of the patients with splenic artery aneurysm was 76.4 years, the youngest being 50 and the oldest 94 .

The greater average age of patients with aneurysm of the splenic artery in the present series is due without a doubt to the age selection exercised in admitting patients to the Cowley Road Hospital. Table I shows that only 29 of the 250 patients investigated were under 60 years of age.

The incidence by decades is shown in Table I and Fig. 7, and is remarkably uniform from 40 to 99 years (extrapolating at the extremes). No relationship is apparent between incidence and age, and therefore, although the numbers of patients investigated under 60 years of age and over 90 are too few to warrant valid deductions being drawn, there is nothing to contradict the supposition that this condition may well occur with similar frequency in younger age groups and would be discovered at necropsy if especially looked for.

This proposition, however, cannot be tested and the effect of age on the incidence of aneurysm of the splenic artery properly assessed except by investigating a large consecutive series of cases comprising all age groups, with particular reference to the splenic artery. Until such information is available it would appear to be more acceptable that the incidence of aneurysm of the splenic artery is nearer the $10.4 \%$ of the present study than the $0.03 \%$ of previous reported series.

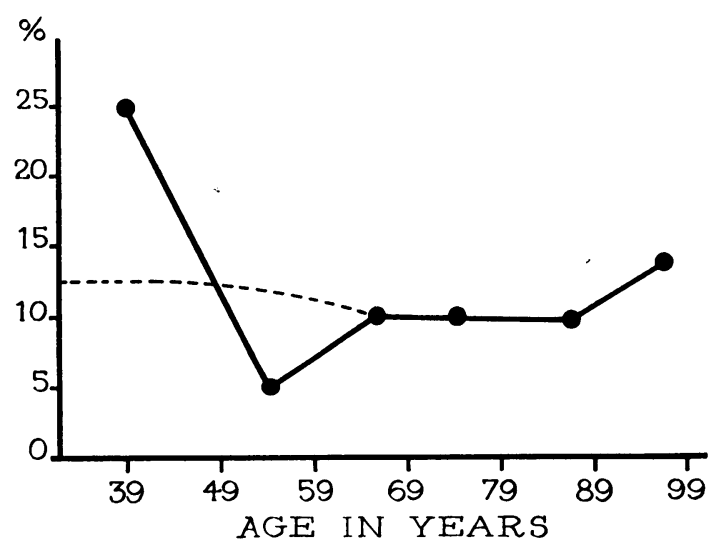

FIG. 7.-Incidence of aneurysm of the splenic artery. (The dotted line is the mean of small numbers.) 


\section{Aetiology}

Of the 125 cases described by Sherlock and Learmonth (1942), 74 were associated with some pathological condition which they considered to be a factor in the aetiology of the aneurysm.

As, however, aneurysm of the splenic artery may be expected to be found quite incidentally in $10.4 \%$ of all routine necropsies, previous views regarding its aetiology clearly demand reconsideration.

In the 204 previously reported cases (Owens and Coffey, 1953), a clearly defined aetiology has been proved in only comparatively few instances. In 36 cases the aneurysms were mycotic due to bacterial endocarditis; in two they were luetic; in 16 congenital; and four "false" aneurysms were traumatic. Sherlock and Learmonth (1942) consider that 34 out of the 125 cases they discussed were due to "arterial degeneration"; Owens and Coffey (1953) record 96 cases as "arteriosclerotic"; Turnbull (1915), however, more specifically stated that medial degeneration was the commonest cause of aneurysm of the splenic artery.

There appears to be an undoubted cause-andeffect relationship between rupture of aneurysm of the splenic artery and late pregnancy, a relationship reviewed in several papers and lately summarized by Chalmers (1949). Altogether 31 cases have been recorded of aneurysm of the splenic artery associated with pregnancy. But this association relates to a complication and not to the aetiology of the condition.

Many of the diseases which have been described as associated with aneurysm of the splenic artery were probably coincidental, e.g., peptic and carcinomatous gastric ulcer, the Banti syndrome, malarial splenomegaly, "wandering spleen", thrombosis of the splenic artery, and Gaucher's disease. The two recorded cases (Owens and Coffey, 1953) of splenic arteriovenous aneurysm may well have been the result of rupture of a true aneurysm of the splenic artery into the splenic vein to which it had become adherent.

The apparent association with splenomegaly and portal hypertension may be fortuitous and not causal and may well have arisen from the greater attention that is directed to the splenic artery in these cases than is normally done in routine post-mortem examinations. Owens and Coffey (1953), however, record 32 such cases and believe that a rise in pressure in the portal system is an important aetiological factor.

In the present series of aneurysm of the splenic artery, none was mycotic; and although the Wassermann or Kahn reactions were positive in two patients, in neither case was syphilis considered to be the cause of the aneurysm. In all of our
26 cases, the aetiology was considered to be degeneration of the media, and although atheroma was present in the wall of all the aneurysms, it was held to be secondary to the medial degeneration. In three cases there were associated congenital abnormalities but these cannot be taken definitely to indicate that the splenic artery aneurysms were of the same (congenital) aetiology. The fact too that most of the aneurysms occurred at bifurcations of the splenic artery, i.e., at the site where congenital defects in the media most commonly occur, although again suggestive, cannot be construed as convincing evidence of a congenital aetiology, for arterial bifurcations are also the site of election for medial degeneration. In this age group, atherosclerosis so often obscures the histological picture that it is rarely, if ever, possible to differentiate with certainty between congenital aneurysms and those due to medial degeneration.

Although of the 26 cases in the present series, 11 were hypertensive and all 26 had gross atherosclerosis of the splenic artery, neither hypertension nor atherosclerosis was considered to be the cause of the aneurysms. Turnbull (1915) comments on the association between aneurysms, medial degeneration, "excessive blood pressure", and gross atheroma, but stated that neither the raised blood pressure nor the atheroma caused the medial degeneration in his cases and hence were not aetiologically responsible for the aneurysm, i.e., the fundamental aetiology of the aneurysm was medial degeneration and not hypertension or atherosclerosis; we concur with this view.

Thus, the only clearly defined and proved aetiological factors are (1) medial degeneration of the arterial wall, (2) mycotic due to bacterial endocarditis, (3) congenital defect in the vessel wall, (4) syphilis, and (5) trauma in the case of "false" aneurysms only.

Pregnancy appears to be a definite factor determining rupture of these aneurysms, and hypertension may also sometimes be responsible for this complication.

We are entirely in agreement with Turnbull (1915) that medial degeneration is by far the commonest cause of aneurysm of the splenic artery and this view is also shared by Russell (personal communication).

Further speculation on the aetiological role of other associated factors is profitless, for not only are such associations tenuous but also the fact that "incidental" aneurysms occur much more frequently than has hitherto been supposed makes the likelihood much greater that the aneurysm and the associated disease are only fortuitously related. 


\section{TREATMENT}

Of the 154 cases collected by Sherlock and Learmonth (1942), 56 (45\%) were diagnosed as the result of rupture. This catastrophe has carried an overall mortality of more than $90 \%$. Owens and Coffey (1953) record a mortality of $76 \%$ after rupture. Treatment by splenectomy before rupture, however, carried a much better prognosis, 18 out of 19 patients in Sherlock and Learmonth's series being cured and $29 \%$ in the Owens and Coffey series. It has therefore been inferred that operation should be undertaken as soon as the condition is diagnosed (Sherlock and Learmonth, 1942). This remains a reasonable inference in spite of the knowledge that splenic artery aneurysms are not only frequent but usually of no clinical importance, for if the diagnosis is suspected it will usually be as the result of some complication (unless discovered incidentally by radiology, see Fig. 6) and it is probable that in such cases rupture may be imminent, the well-recognized "two-stage" rupture. However, the fact that aneurysm of the splenic artery is apparently an innocuous condition occurring in over $10 \%$ of all elderly patients, and the considerable mortality among the (treated) cases assembled by Owens and Coffey (1953), provides a strong argument against routine surgery in patients without symptoms, a possible exception being made in pregnancy and in severe hypertension.

\section{CONCLUSIONS}

In 250 consecutive routine post-mortem examinations made on patients dying in the Geriatric Unit, Cowley Road Hospital, Oxford, 26 cases were found to have aneurysms of the splenic artery, an incidence of $10.4 \%$. None of the patients had symptoms referable to the aneurysm. This is a very much higher incidence than the total of 262 cases previously described in the world's literature suggests and than the stated incidence derived from the several large necropsy surveys. The condition occurs more commonly in females than in males. The literature of the condition is comprehensively reviewed.

Medial degeneration is considered to be the commonest aetiological factor.

The implications of the findings reported here are discussed.

\section{BIBLIOGRAPHY}

Abrams, A. B., and Kauder, W. G. (1944). Amer. J. Surg., 66, 284-286.

Ahrens, M. L. A. G. (1892). Inaug. Dissert. (Zwei Fälle von gebortstenen Aneurysmen der Arteria lienalis und hepatica). Abel, Greifswald.

Anderson, W., and Gray, J. (1929). Brit. J. Surg., 17, 267-277.

Anderson, W., and Gray, J. (1929). Brit. J. Surg., 17,

Ayer, J. B. (1883). Boston med. surg. J., 108, 148-149. 24, 450-451.

Baumgartner, E. A., and Thomas, W. S. (1924). Surg. Gynec. Obstet., 39, 462-471.
Beaussenat (1892), Zbl. all. Path. path. Anat., 3, 983-984.

Beaussier, M. (1770). J. Méd. Toulouse, 32, 157.

Berger, J. S., Forsee, J. H., and Furst, J. N. (1953). Ann. Surg., $137,108-110$.

Berry, J. A. (1927). Lancet, 1, 490.

Bertrand, P., and Clavel, C. (1929). Lyon chir., 26, 641-672.

Bertrand, P., and Clavel, C. (1929). Lyon chir., 26,

Bochkor, A. (1928). Orv. Hetil., 72, 536-537 (Elvèrzés a lép Veröértag ulatából).

Boecker, P. (1931). Zbl. Chir., 58, 1375-1377.

Bohler, E. (1933). Bull. Soc. Obstét. Gynéc. Paris, 22, 707.

Bosdorff, C. H. (1889). Uber Häufigkeit und Vorkommen der Aneurysmen nach den Ergebnissen von 3108 Sectionen (Inaug. Dissert. Böckel, Kiel.)

Bosse, M. D., and Strang, J. M. (1942). Arch. Path. (Chicago), 33, 372-379.

Botman, H. Reported by Specken, J. J. H., and DeBruyn, N.J.C. (1950).

Bremer, J. K., and Fichardt, T. (1955). S. Afr. med. J., 29, 8-13.

Brockman, R. St. Leger (1930). Brit. J. Surg., 17, 692-693.

Bruce, J. (1937). Lancet, 1, 1451-1454.

Cabot, R. C. (1935). New Engl. J. Med., 212, 991-993.

Cady, J. B. (1937). Guthrie Clin. Bull (Sayre), 6, 145.

Carrington, R. E. (1885). Trans. path. Soc. Lond., 36, 135-138.

Chalmers, J. A. (1949). Brit. J. Surg., 37, 86-90.

Coffey, R. J., and Blumberg, J. J. (195i). U.S. armed Forces med. J., 2, 803-814.

Colangelo, C. (1955). Illinois med. J., 108, 223-225.

Cole, W. H. (1949). Surg. Clin. N. Amer., 29, $1435-1443$.

Conforth, E., and Carangelo, J. (1946). Amer. J. Obstet, Gynec., $51,429.431$.

Corson, E. M. (1869). Med. surg. Reporter, 20, 351.

Cosgrove, G. E., Watts, J. C., and Kaump, D. H. (1947). Amer. J. clin. Path., 17, 372-382

Crisp, E. (1847). A Treatise on the Structure, Diseases and Injuries of the Blood-Vessels, p. 251. Churchill, London.

Crossman, L. W., Haley, M. D., and Carroll, R. B. (1954). Med. Rec. (Houston), 48, 889-894.

Dahm, M. (1936). Röntgenpraxis, 8, 802-804.

Dahm, M. (1936). Röntgenpraxis, 8, 802-804.

Darnall, C. F. (1885). Trans. Iowa med. Soc., 6, 140-

Davidson, A. (1884). Lpool med.-chir. J., No. 6, p. 210.

Davis, B. F. (1925). J. Amer. med. Ass., 84, 200-201.

Dobson, L., Morse, D., and Covert, J.'(1947). Stanf. med. Bull., 5, 39-42.

Donaldson, G. A., and Hamlin, E., Jr. (1950). New Engl. J. Med., 243, 369-373.

Donati, M. (1933). Reported by Tabanelli, M. (1938).

Downs, C. R., Hopeman, A. R., Todd, W. A., Jr., and Mathewson, C., Jr. (1955). Ann. Surg., 141, 268-272.

Dudgeon, H. (1941). Tex. St. J. Med., 36, 664-667.

Emmerich, O. (1888). Inaug. Dissert. (Ueber die Haüfigkeit der inneren Aneurysmen in München). Ernst, Munich.

Eppinger, H. (1887). Arch. klin. Chir., 35, Suppl., pp. 1-563.

Evpinger, H. M. (1954). Lancet, 2, 846-847.

Faebrmann, I., and Ugrümow, B. (1925). Arch. klin, Chir., 137 193-197.

Fearnsides, E. G. (1916). Brain, 39, 224-296.

Feldman, M. (1955). Amer. J. dig. Dis., 22, 48-50.

Ferrari, E. (1938). Cuore e Circol., 22, 585-604.

Fitzwilliams, D. C. L. (1924). Brit. med. J., 2, 803-804.

Forbus, W. D. (1929). Zbl. allg. Path., 44, 243-245.

Fretheim, B. (1938). Norsk Mag. Laegevidensk., 99, 1230-1246.

Freitas, T. (1941). Neurobiologia, 4, 230-241.

Fuchs, G. (1937). Röntgenpraxis, 9, 467-469.

Gallagher, H. W., and Hudson, K. (1954). Brit. med. J., 2, 1209-1210.

Garland, J. (1921). Boston med. surg. J., 184, 385-386.

Ghabrial, F. (1950). J. Egypt. med. Ass., 33, 411-423.

Gillam, J. F. E. (1942). Brit. med. J., 1, 69-70.

Gillam, J. F. E. (1948). Brit. J. Surg., 36, 203-204.

Golden, R. (1938). Diagnostic Roentgenology, p. 932. Nelson, New York.

Goodhart, J. F. (1889). Trans. path. Soc. Lond., 40, 67-70.

Goullioud, M. (1928). Lyon méd., 142, 353-366.

Greco, A., and Di Lollo, F. (1954). Arch. De Vecchi Anat., pat. 20,935-957

Günther, G. W. (1938). Bruns' Beitr. klin. Chir., 168, 457-466.

Guy, C. C. (1939). Surgery, 5, 602-608.

Haffiner, J. (1936). Acta. radiol. (Stockh.), 17, 602-608.

Harnett, W. L. (1922). Indian med. Gaz., 57, 457-460.

Heppner, C. L. (1872). St. Petersb. med. Z., M.S. 3, 220-238.

Heuveldop (1934). Zbl. allg. Path. path. Anat., 61, 277-279.

Hill, R. M., and Inglis, A. (1955). Brit. J. Surg., 42, 408-412. Hoeven, van der. Reported by Specken, J. J. H., and DeBruyn,

Hogeman, K. E. (1943). Nord. Med., 17, 189

Högler, F. (1920). Wien. Arch. inn. Med., 1, 543-559.

Holland, Sir Eardley, and Bourne, A. (1959). British Obstetric and Gynaecological Practice. Heinemann, London.

Hughes, E. S. R., and Joske, R. A. (1955). Med.J. Aust., 2, 188-190.

Hughes, E. S. R., and Joske, R. A. (1955). Med. J. Aust.
Hunt, E. L. (1928). Amer. J. med. Sci., 176, 195-200.

Hunt, E. L. (1928). Amer. A. med. A. (1956). A Textbook of Surgical Pathology. Churchill, London.

Israelski, M. (1930). Röntgenpraxis, 2, 670-672. 
Jourden (1892). Z Zbl. allg. Path. path. Anat., 3, 36.

Kolb, O. (1940). Dtsch.Z. ges. gerichtl., Med. (Orig.), 33, 254-255.

Lamy, M., and Ameline, A. (1954). Mém. Acad. Chir., 80, 577-584.

Lancereaux, E. (1879). Traité d'Anatomie Pathologique, Vol. 2, p. 910 . Delahaye \& Lecrosnier, Paris.

Lang, S. J., and McCarter, J. C. (1948). Quart. Bull. Northw. Univ. med. Sch., 22, 298-300.

Langsam, M., Lewitan, A., and Wilensky, N. D. (1954). N.Y. St. J. Med., 54, 3113-3114.

Lazarus-Barlow, W. S. (1899). Trans. path. Soc. Lond., 50, 57.

Lebert (1879). Cited by Quincke in Ziemssen's Handbuch der Speciellen Pathologie und Therapie, Vol. 1, p. 2. Vogel, Leipzig.

Le Fevre, G. L., and Pettis, E. M. (1935). J. Mich. med. Soc., 34, 358-361.

Lennie, R. A., and Sheehan, H. L. (1942). J. Obstet. Gynaec. Brit. Emp., 49, 426-436.

Leudet, M. (1852). Gaz. Hôp., 25, 583

Levy, D. F. (1941). Conn. med. J., 5, 567-569.

Lindboe, E. F. (1932). Acta chir. scand. 72, 108-114.

Lindbom, O. (1914). Mitt. Grenzgeb. Med. Chir., 27, 912-933.

Lower, W. E., and Farrell, J. I. (1931). Arch. Surg. (Chicago), 23, $182-190$.

Lubitz, J. M., and Scott, D. W., Jr. (1947). Ann. intern. Med., $26,594-599$

Lundwall, K., and Gödl, A. (1923). Arch. Gynäk., 118, 177-184.

Machemer, W. L., and Fuge, W. W. (1939). Arch. Surg. (Chicago), 39, $190-204$.

Macleod, D., and Maurice, T. (1940). Lancet, 1, 924-925.

Maljatzkaja, M. I. (1934). Beitr. path. Anat., 94, 81-110.

Mallet-Guy, P. (1931-32). Arch. franco-belg. Chir., 33, 1064-1066.

Marshall, C. J. (1922). Brit. J. Surg., 9, 570-571.

Martin, F. E. (1945). U.S. nav. med. Bull., 44, 152-153.

Mascheroni, H. A., Reussi, C., and Lafage, L. A. (1943). Arch. argent. Enferm. Apar. dig., 18, 201-210.

Matronola, G. (1940). Policlinico, Sez. prat., 47, 993-1008.

Mayer, E. (1928). Zbl.. Gynäk., 52, 754-757.

Mayet, M. (1879). Ann. Soc. Méd. Lyon, 25, 44

Mend, M. (1879) (1954). Ann. paul. Med. Cir., 68, 73-83.

Meunier, J. (1928). Rupture des aneurismes spleniques. Thèse de Lyon. Milone, S. (1952). Arch. ital. Chir., 75, 427-440.

Mondor, H. (1937). Diagnostics urgents, abdomen, 3rd ed., pp. 658-662. Masson, Paris.

Monro, T. K. (1906). Trans. Glasg. path. clin. Soc., 11, 92-93.

Morseletto. Reported by Zannini, L. (1880).

Muir's Textbook of Pathology, 7th ed. (1958). Arnold, London.

Müller, E. (1902). Zus statistik der Aneurysmen. (Inaug. Dissert.)

Fischer, Jena.
Mulley, K. (1918). Bruns' Beitr. klin. Chir., 111, 205-214.

Murphy, B. (1942). Lancet, 1, 704-705.

Naegeli, Y. (1934). Schweiz. med. Wschr., 11, 652-653.

Näher, H. (1926). Dtsch. Z. Chir., 198, 118-124.

Nevin, S., and Williams, D. (1937). Lancet, 2, 955-958.

Nodes, J. D. S., and Hinds, F. (1900). Trans. obstet. Soc. Lond., 42, 305-310.

Ogden, J. K. (1948). Brit. med. J., 1, 389-391.

Ophüls, W. (1926). Stanf. Univ. Publ. med. Sci., 1, 127.

Ortner, N. (1921). Wien. Arch. inn. Med., 2, 185-186.

Osborne, S. E. (1936). Lancet, 1, 1007-1008.

Osler, W. (1889). Trans. path. Soc. (Philad.), 14, 127

- (1901). Practice of Medicine, 4th ed., p. 787. Appleton, New York.

Ostling, K. (1938). Acta obstet. gynec. scand., 18, 444-465.

Owens, J. C., and Coffey, R. J. (1953). Abstr. Wld Surg. Obstet. Gynec., 97, 313-335.

Palmer, T. H. (1950). New Engl. J. Med., 243, 989-993.

Parker, E. (1844a). Dublin J. med. Sci., 26, 124.

Parrella44b). Edinb. med. surg. J., 62, 132-133.

Parrella, G. S. (1955). Newit. C. G. (1937). Brit. J. Surg., 24, 708-712.

Pasternack, J. C., and Shaw, J. R. (1939). New Orleans med. surg. J., 92, 94-98.

Pemberton, J. de J., and Kiernan, P. (1945). Surg. Clin. N. Amer., $25,880-890$.

Pinas, S. R. (1945). Amer. J. clin. Path., 15, 609-612.

Poidevin L. O. S. (1955). Med. J. Aust., 1, 922-923.

Ponfick (1873). Virchows Arch. path. Anat., 58, 528-571.

Pujals, L. D. (1932). Rev. méd. Rosario, 7, 39-45.

Pujarna, M. H. (1953). Northw. Med. (Seattle), 52, 556.

Registrar General (1959). Statistical Review of England and Wales for 1957: Part II. Tables, Civil. H.M.S.O., London.

Remizov, A. A. (1935). Sovetsk. Khirurg., No. 8, pp. 136-145.

Remmelts, R. (1928). Ned. T. Verlosk., 33, 41-44.

Reyburn R. (1893). Clinical History of the Case of President James Abrum Garfield. Privately published. Washington, D.C.

Reynolds, H. W. (1906). S. Afr. med. Rec., 4, 267.

Rhame, J. S. (1928). Ann. Surg., 88, 212-215.

Ricci, F. (1924). Boll. Soc. med.-chir. Pavia, 36, 231-238.

Riemenschneider, P. A. (1955). Amer. J. Roentgenol., 74, 872-873.

Rob, C., and Smith, R., editors. (1956). Operative Surgery, Vol. 2. Butterworth, London.

Robitschek (1926). Wien. klin. Wschr., 39, 1349.

Rochet, P., and Peycelon (1927). Lyon méd., 140, 158-161.

Rolleston, H. D. (1899). Trans. path. Soc. Lond., 50, 55-56.
Romanis, W. H. C. (1935). Lancet, 2, 1275-1277.

Ronnen, J. R. von (1953). Acta radiol. (Stockh.), 39, 385-400

Rooy, A. H. M. J. van (1927). Ned. Maandschr. Geneesk., 14, 507-513.

Roux, M., and Binet, J. P. (1954). Presse méd., 62, 400-403.

Rudnev, N. M. (1936). Sovetsk. Khirurg., No. 3, pp. 534-536.

Saenger, H. (1926). Zbl. Gynäk., 50, 1324-1326.

Säfwenberg, O. (1937). Acta radiol.' (Stockh.), 18, 481-490.

Santesson (1848). Svenska Läk.-Sällsk. Forh,, pp. 12-17.

Schoenfeld, B. (1935). Frage des Milzarterien-aneurysmas, p. 15. Inaug. Dissert., Grettinyen: Dieterichsen Universitaets. Buchdruckerei,

Scholz, O. (1956), Zbl. Chir., 81, 1768-1771.

Schroeder, C. (1924). Arch. klin. Chir., 132, 175-180.

Schrotter, L. von (1898). In Specielle Pathologie und Therapie, ed. H. Nothnagel. Hölder, Vienna.

Schultze, W. (1905). Beitr. path. Anat., 38, 374-387.

Schuster, N. H. (1937). J. Path. Bact., 44, 29-39.

Seids, J. V., and Hauser, H. (1941). Radiology, 36, 171-180.

Selter, P. (1893). Virchows Arch. path. Anat., 134, 189-199.

Sered, H., and Steiner, L. M. (1935). Amer. J. Obstet. Gynec., 29, 606-6

Sewering, H. J. (1941). Inaug. Dissert., Munich (Ein Beitrag zn. den Aneurysmen der Milzarterie, p, 25). Union Druckerei,

Stuttgart.
Shallow, T. A., Herbut, P. A., and Wagner, F. B., Jr. (1946). Surgery, 19, $177-185$.

Sheehan, H. L., and Falkiner, N. M. (1948). Brit. med. J., 2, 11051106.

Sheer (1933). Treatise. Zurich, 16, 8.

Sherlock, S. P. V., and Learmonth, J. R. (1942). Brit. J. Surg., 30 , $151-160$

Sherwin, B., and Gordimer, H. (1950). Ann. Surg., 131, 599-603.

Shumway, N. E., and Peyton, W. T. (1951). Surgery, 30, 1012-1015.

Sigwart, H. (1953). Chirurg., 24, 318-319.

Sjovall. Reported by Gunther, G. W. (1938).

Smith, A. H. (1905). President Garfield and Elberon. Amer. Med. (Philad.), 9, 118.

Smith, H. B. W. (1911). Brit. med. J., 1, 83

Smith, W. R. (1923). J. Amer. med. Ass., 80, 1692.

Specken, J. J. H., and DeBruyn, N. J. C. (1950). Ned. T. Geneesk., Sperling, L. (1940).

Surgery, 8, 633-638.

Springorum, W. (1933). Virchows Arch. path. Anat., 290, 733-748.

Stener, B. (1955). Acta chir. scand., 108, 344-350.

Stern, R. (1925). Klin. Wschr., 4, 154-156.

Tabanelli, M. (1938). Arch. ital. Chir., 54, 629-662.

Tagart, R. E. B. (1952). Brit. J. Surg., 39, 469-471.

Tanner, F. N., and Miller, H. B. (1955). Neb. St. med. J., 40, 9-11.

Tarozzi, G. (1904). Zbl. allg. Path. path. Anat., 15, 700.

Taylor, R. S., and Teacher, J. H. (1911). Glasg. med. J., 75, 249-256. Texier, Baumgartner, Ronneaux, and Gadbreau (1930). Bull. Soc.

Thiersch, H. (1935). Beitr. path. Anat., 96, 147-176.

Thorel, C. (1910). Ergbn. allg. Path. path. Anat., 14 (2), 663-675.

Toes, N. A. (1956). Brit. med. J., 1, 495.

Tomsykoski, A. J., Stevens, R. C., Izzo, P.A., and Rodriquez, C. E. (1953). Amer. J. Obstet. Gynec., 66, 1264-1270.

Tonge, J. I. (1948). Med. J. Aust., 2, 119-122.

Trevor, R. S. (1903). Trans. path. Soc. Lond., 54, 302-308.

Trimble, W. K., and Hill, J. H. (1942). Arch. Path. (Chicago),

Turnbull, H. M. (1915). Quart. J. Med., 8, 201-254.

Turner, F. C. (1885). Trans. path. Soc. Lond., 36, 151.

Vedel-Jensen, N. (1955). Ugeskr. Laeg., 117, 1022-1026.
Villard, E., and Murard, J. (1912). Arch. gén. Chir., 8, 749-753.

Vink, L. P. H. J. de, and Linde, H. M. van der (1950). Ned. T.

Wallgren, C. G. (1954). Finska Läk.-Sällsk. Handl., 97, 244.

Walz (1908). Dtsch. med. Wschr., 34, 175.

Ward-McQuaid, J. N. (1958). Brit. med. J. 1, 1448-1452.

Ware, J. (1856). Boston med. surg. J., 54, 297

Weigert, C. (1886). Virchows Arch. path. Anat., 104, 26-30.

Weinberger, M. (1907). Z. klin. Med., 62, 457-480.

Weiss, J. von Quoted by Schrotter, L.'(1898).

Weissenborn, W. (1936). Chirurg., 8, 883-890.

Wesenberg, W. (1912). Z Zbl. Gynäk., 36, 463-466.

West, S. (1885). Lancet, 1, 518-519.

Wilke (1926). Klin. Wschr., 5, 1899.

Williams, R. W., and Harris, R. B. (1954). A.M.A. Arch. Surg., 69, $530-532$.

Winckler, V. (1905). Z Zbl. Chir., 32, 257-260.

Wohl, M. G. (1925). Ann. Surg., 82, 246-249.

Wood, W. S., and Hall, B. (1954). A.M.A. Arch. intern. Med., 93, $633-640$

Woolley, P. G. (1917). J. Lab. clin. Med., 2, 525-535.

Yolland, R. H. (1925). Brit. med. J., 1, 600.

Zahn, F. W. (1891). Virchows Arch, path. Anat., 124, 238-259.

Zannini, L. (1880). Gazz. med. ital., 23, 296-298. Zeluff, G. W., and Parsonnet, V. (1951). Ann. intern. Med., 35, $\underset{\text { Gynec. Obstet., 95, }}{\text { Zummo, P12-518. }}$ and Uznanski, M. (1952). Surg. 